\title{
Family support and quality of life of schizophrenia patients
}

\author{
Made Setiawati ${ }^{1}$, Anak Agung Sagung Sawitri ${ }^{2}$, Cokorda Bagus Jaya Lesmana ${ }^{3}$ \\ ${ }^{1}$ Badung District Health Office, Sempidi, Badung, Bali, Indonesia \\ ${ }^{2}$ Department of Public Health and Preventive Medicine Faculty of Medicine, Universitas Udayana, Bali, Indonesia \\ ${ }^{1,2}$ Master Program of Public Health, Faculty of Medicine, Universitas Udayana, Bali, Indonesia \\ ${ }^{3}$ Department of Psychiatry Faculty of Medicine, Universitas Udayana, Bali, Indonesia \\ ${ }^{3}$ Sanglah General Hospital, Bali, Indonesia
}

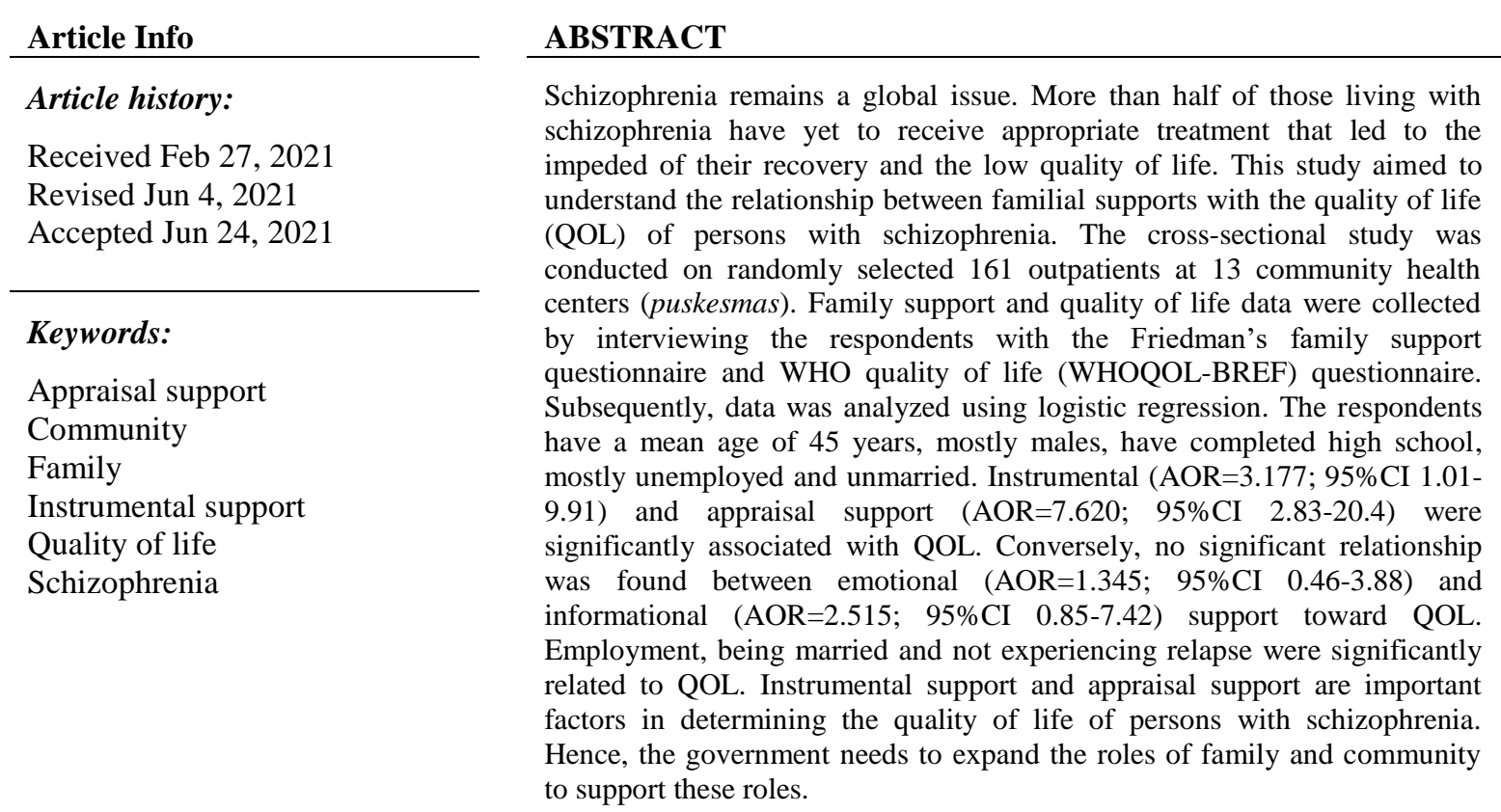

This is an open access article under the CC BY-SA license.

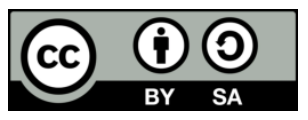

\section{Corresponding Author:}

Anak Agung Sagung Sawitri

Department of Public Health and Preventive Medicine

Faculty of Medicine

Universitas Udayana

Jalan PB Sudirman, Bali, Denpasar, Indonesia

Email: sagung_sawitri@unud.ac.id

\section{INTRODUCTION}

Schizophrenia is a global issue with an estimated 21 million people living with this condition, which is $0.2-0.4 \%$ of the world's population [1] and one of the top 20 contributors to disability [2]. The Riset Kesehatan Dasar (Riskesdas) or Basic Health Research reports a four-fold increase in prevalence of schizophrenia in Indonesia from 1.7 cases (2013) to 7.0 cases per 1000 persons (2018). Bali Province reports the highest prevalence in Indonesia with 11 cases per 1000 persons [3]. Additionally, schizophrenia ranks the first out of 10 most common mental health illnesses seen at Bali Province Mental Health Hospital, as outpatients and inpatients [4]. Badung Regency is one of the regencies in Bali Province with low prevalence at 2.5 cases per 1000 compared to provincial and national rates [3], [5]. 
The World Health Organization (WHO) reports more than $50 \%$ of persons with schizophrenia have not received appropriate treatment [1]. The Ministry of Health in Indonesia further emphasizes the importance of managing severe mental health disorders through the Ministry of Health Regulation No. 4 in 2019 on Minimum Care Standards, which states that mental health examination has to encompass mental status assessment and interview, education on medication adherence and service referral [6]. This regulation demonstrates the current focus on medicating the patients. However, the emphasis on care for patients with mental health disorders should be on improving quality of life [7] which consist of physical and psychological health, independence on activities of daily living, self-confidence, social interaction, social and environmental support and the attempt to empower one self to obtain income [8], [9].

Previous studies demonstrated the relationship between family support and care environment for patients with schizophrenia, including quality of life. Family support has been reported to significantly impact the decrease in symptom recurrence after discharge [10] and decrease in relapse [11], [12]. One study examining family support and quality of life among persons with schizophrenia mentions family support without providing details on the components of support [10]. According to Friedman, support to patients include emotional support such as showing care and appreciation, instrumental support such as preparing and monitoring medication administration, informational support such as providing advise on how to take medication, appraisal support with giving praising the patient when they adhere to prescribed medication schedule [13]. In other studies, the quality of life is often associated with sociodemographic [14], [15] and clinical symptoms of persons with schizophrenia [16]. These studies are often set in the clinical or hospital settings [12], [14]-[16], and there has limited similar studies in the community or outpatient settings [17].

Badung Regency, one of the study locations, has an innovative health insurance program for its residents, including those who experience mental health disorders. Each village has its own ambulance that is used to bring sick residents who are unable to access healthcare facilities on their own. This was implemented to optimize the healthcare services received by community members. With this innovation, those who experience mental illness can have better quality of life. The current mental health program in Badung is still focused on finding cases, providing guidance, and educating family members. However, they have yet to provide facilities such as halfway houses available in Denpasar, which provide programs that empower, advise and rehabilitate patients after discharge, in addition to efforts to increase medication adherence [18]. Based on the issues identified, this study aimed to understand the relationship between family support toward quality of life among persons with schizophrenia residing in Badung Regency.

\section{RESEARCH METHOD}

This was an observational study with cross-sectional design conducted in Badung Regency, Bali, Indonesia between May and June of 2020. This study involved 161 outpatients selected through systematic random sampling from 503 outpatients registered at all (13) community health centers in Badung Regency. Patients are eligible to participate if they are at least 18 years of age at the time of interview, in a stable and cooperative state, currently living with family, willing to participate, and do not have other coexisting conditions such as experiencing developmental issues, dementia, epilepsy, congenital physical deformities such as blindness, deafness, immobile, mute, and no history of narcotics use and other substance abuse. In cases where selected participants did not fulfill the eligibility criteria, sample substitution was performed by selecting the respondent listed above the initially selected sample. Sample size was calculated using the formula for two proportion cross-sectional study with a confidence interval of $95 \%$, power of $80 \%$, precision of $20 \%$ where the proportion of patients with good quality of life receiving good support is $82.1 \%$ ( $\mathrm{P} 1=0.82)$, and the assumption that $\mathrm{P} 2=0.62$ for the proportion of patients with good quality of life and suboptimal family support. The calculation generated a minimal sample size of 146 patients, with an additional $10 \%$ to anticipate for low response rate, resulting in a sample size of 161. At the time of data collection, there were 19 respondents who were excluded due to unstable clinical conditions and inability to cooperate. Sample substitution was conducted until the sample recruited reached 161 patients.

Data collection was performed by five trained interviewers by visiting the respondent's home and interviewing them in person after obtaining the patient's and family's consent. Prior to the interview, researchers and interviewers provided explanation on the study procedure and ethical considerations such as confidentiality, voluntary participation, and the right to withdraw or not participate. Only respondents who were prepared to participate and signed the informed consent were involved in the study. The WHOQOLBref in Indonesian language [19] was used to assess quality of life and the Friedman questionnaire [20] was also used to assess family support with additional questions on sociodemographic characteristics and other variables that are considered to impact quality of life, such as medication adherence, stressors, relapse and coping ability (coping skills). Medication adherence is assessed using the Morisky Medication Adherence scale (MMAS) [21] which rates the behavior of patients with schizophrenia in abiding by prescribed 
medication regimen. Stressor refers to the experiences that cause psychological stress within the past month and relapse refers to the reemerging of symptoms within one year of being discharged, whereas coping ability points to the attempt made by patients in protecting themselves from psychological stress. Quality of life is measured using 26 statements on the perception of person with schizophrenia on their physical health (7), psychological wellbeing (6), social environment (3) and environment (6) and two statements on overall quality of life [19]. Each statement can be scored with a lowest possible score of 1 and highest possible score of 5 whereby the higher the score, the higher the quality of life. The overall mean score of the domain and score of each domain of quality of life were calculated separately. Family support can be measured with a total of 24 statements consisting of physical support (6), psychological support (6), appraisal support (6) and informational support (6). Each statement can be given a lowest possible score of 1 and highest possible score of 4. Overall family support was summed of scores off all supports and was categorized into low and high family support based on its median. Descriptive analysis was performed on data on sociodemographic characteristics, external variables, family support and quality of life, and presented in percentages. Quality of life was connected to the variables on sociodemographic characteristics, external variables, and family support to determine differences in proportion among variables using chi-square analysis. Subsequently, logistic regression analysis was performed to test the relationship between family support and other variables with p-values of $<0.25$ on the bivariate analysis of quality of life. This study has been granted ethics approval by the Faculty of Medicine Udayana University-Sanglah General Hospital Ethics Committee with number No. 850/UN14.2.2VII.14/LT/2020 on April 22, 2020.

\section{RESULTS}

Results demonstrate that the mean age of respondents is 45 years, mostly males $(61.5 \%)$, have graduated high school (36.6\%), unemployed (62.1\%), and unmarried (55.9\%). Further details are presented in Table 1.

Table 1. Sociodemographic characteristics of persons with schizophrenia

\begin{tabular}{lcc}
\hline Respondent characteristics & $\begin{array}{c}\text { Frequency (f) } \\
(\mathrm{n}=161)\end{array}$ & Percent $(\%)$ \\
\hline Age (Mean (years) \pm SD), (Min-Max) & $(45 \pm 11.0),(19-71)$ & \\
$\quad$ <45 years & 82 & 50.9 \\
$\quad \geq 45$ years & 79 & 49.1 \\
Gender & & \\
$\quad$ Male & 99 & 61.5 \\
Female & 62 & 38.5 \\
Education & & 5.6 \\
$\quad$ Have never been to school & 9 & 14.3 \\
Did not graduate primary school & 23 & 19.3 \\
Graduated primary school & 31 & 19.9 \\
$\quad$ Graduated middle school & 32 & 36.6 \\
$\quad$ Graduated high school & 59 & 4.3 \\
$\quad$ Graduated from higher education & 7 & 37.9 \\
Employment status & & 62.1 \\
$\quad$ Employed & 61 & \\
$\quad$ Unemployed & 100 & 44.1 \\
Marital status & & 55.9 \\
$\quad$ Married & 71 & \\
$\quad$ Unmarried & 90 &
\end{tabular}

Table 2 demonstrates overall family support to the respondents based on each component. High ratings for family support is reported by a portion of respondents $(51.6 \%)$ and as high as $73.5 \%$ respondents with high family support report high quality of life, indicating a significant relationship between the two. In the support component, there is a tendency for respondents receiving with high emotional, instrumental, informational and appraisal support to report higher quality of life compared to those who receive lower family support for the same components. Further descriptive analysis results (table was not shown) indicate the that mean score (SD) on quality of life is as high as $83.45 \pm 15.1$, with the lowest score of 52 and highest score of 115. The mean score (SD) of each domain in quality of life is as follows: physical domain $59.0 \pm 16.9$, psychological domain $55.3 \pm 16.7$, social domain $45.8 \pm 19.0$, and environment domain $56.2 \pm 13.5$. It is observed that respondents have the highest mean score in the physical domain and lowest score in social domain. 
Table 3 demonstrates that respondents with $<45$ years of age $(52.4 \%)$, female $(53.2 \%)$, attained high school equivalent or higher education $(57.6 \%)$, employed $(73.8 \%)$, married $(59.2 \%)$, adherent to medication regimen $(62.2 \%)$, with no relapse $(59.6 \%)$, no stressor $(65.3 \%)$, and have coping abilities $(61.4 \%)$ report higher quality of life compared to respondents who are $\geq 45$ years of age $(48.1 \%)$, male $(48.5 \%)$, unemployed $(36.0 \%)$, unmarried $(43.3 \%)$, non-adherent to medication regimen $(35.2 \%)$, experience frequent relapse $(27.7 \%)$, experience stressors $(43.8 \%)$ and unable to cope $(38.5 \%)$. A number of variables proven to be significantly associated with the respondents' quality of life include employment status $(\mathrm{P}=0.000)$, marital status $(\mathrm{P}=0.033)$, medication adherence $(\mathrm{P}=0.001)$, relapse episodes $(\mathrm{P}=0.000)$, stressors $(\mathrm{P}=0.016)$ and coping $(\mathrm{P}=0.005)$. In the multivariate analysis, all variables with $\mathrm{p}$-value $<0.25$ were included in the multivariate model.

Table 2. Relationship between family support and quality of life for persons with schizophrenia

\begin{tabular}{|c|c|c|c|c|c|}
\hline \multirow[b]{2}{*}{ Type of support } & \multicolumn{3}{|c|}{ Quality of life $(\mathrm{n}=161)$} & \multirow[b]{2}{*}{$\begin{array}{l}\text { Total } \\
(\%)\end{array}$} & \multirow[b]{2}{*}{$\mathrm{p}$} \\
\hline & $\begin{array}{l}\text { Median (IQR); } \\
\text { Min-Max }\end{array}$ & $\begin{array}{l}\text { High } \\
\text { n (\%) }\end{array}$ & $\begin{array}{c}\text { Low } \\
\mathrm{n}(\%)\end{array}$ & & \\
\hline Family support (overall) & $70(18) ; 30-96$ & & & & \\
\hline High & & $61(73.5)$ & $22(26.5)$ & $83(51.6)$ & $0.000 *$ \\
\hline Low & & $20(25.6)$ & $58(74.4)$ & $78(48.5)$ & \\
\hline Emotional support & $19(4) ; 10-24$ & & & & \\
\hline High & & $56(60.9)$ & $36(39.1)$ & $72(57.1)$ & \\
\hline Low & & $25(36.2)$ & $44(63.8)$ & 69 (42.9) & $0.002^{*}$ \\
\hline Instrumental support & $17(6) ; 7-24$ & & & & \\
\hline High & & $56(68.3)$ & $26(31.7)$ & $82(50.9)$ & $0000 *$ \\
\hline Low & & $25(31.6)$ & $54(68.4)$ & $79(49.1)$ & 0.000 \\
\hline Informational support & $16(6) ; 6-24$ & & & & \\
\hline High & & $59(72.0)$ & $23(28.0)$ & $82(50.9)$ & \\
\hline Low & & $22(27.8)$ & $57(72.2)$ & $79(49.1)$ & $0.000^{n}$ \\
\hline Appraisal support & $18(6) ; 7-24$ & & & & \\
\hline High & & $68(76.4)$ & $21(23.6)$ & $89(55.3)$ & \\
\hline Low & & $13(18.1)$ & $59(81.9)$ & $72(44.7)$ & $0.000^{2}$ \\
\hline
\end{tabular}

Table 3. Relationship between sociodemographic characteristics, medication adherence, stressors, coping, relapse and quality of life among persons with schizophrenia

\begin{tabular}{|c|c|c|c|c|c|}
\hline \multirow[b]{2}{*}{ Variable } & \multirow[t]{2}{*}{$\begin{array}{c}\text { Median (IQR); } \\
\text { Min-Max }\end{array}$} & \multicolumn{2}{|c|}{ Quality of life $n=161$} & \multirow[t]{2}{*}{$\begin{array}{c}\text { Total } \\
(\%)\end{array}$} & \multirow[b]{2}{*}{$\mathrm{p}$} \\
\hline & & $\begin{array}{l}\text { High } \\
\text { n (\%) }\end{array}$ & $\begin{array}{c}\text { Low } \\
\text { n }(\%)\end{array}$ & & \\
\hline \multicolumn{6}{|l|}{ Age } \\
\hline$<45$ years & & $43(52.4)$ & $39(47.8)$ & $82(50.9)$ & 0.637 \\
\hline$\geq 45$ years & & $38(48.1)$ & $41(51.9)$ & $79(49.1)$ & \\
\hline \multicolumn{6}{|l|}{ Gender } \\
\hline Male & & $48(48.5)$ & $51(51.5)$ & $99(61.5)$ & 0.628 \\
\hline Female & & $33(53.2)$ & $29(46.8)$ & $62(38.5)$ & \\
\hline \multicolumn{6}{|l|}{ Education } \\
\hline Highschool equivalent/ higher & & $38(57.6)$ & $28(42.4)$ & $66(40.9)$ & 0.150 \\
\hline Middle school equivalent/lower & & $43(45.3)$ & $52(54.7)$ & $95(59.1)$ & \\
\hline \multicolumn{6}{|l|}{ Employment status } \\
\hline Employed & & $45(73.8)$ & $16(26.2)$ & $61(37.9)$ & $0.000 *$ \\
\hline Unemployed & & $36(36.0)$ & $64(64.0)$ & $100(62.1)$ & \\
\hline \multicolumn{6}{|l|}{ Marital status } \\
\hline Married & & $42(59.2)$ & $29(40.8)$ & $71(44.1)$ & $0.033 *$ \\
\hline Unmarried & & $39(43.3)$ & $51(56.7)$ & $90(55.9)$ & \\
\hline Medication adherence & $6(5) ; 0-8$ & & & & \\
\hline Adherent & & $56(62.2)$ & $34(37.8)$ & $90(55.6)$ & $0.001 *$ \\
\hline Non-adherent & & $25(35.2)$ & $46(64.8)$ & $71(44.1)$ & \\
\hline \multicolumn{6}{|l|}{ Relapse episodes } \\
\hline Not present & & $68(59.6)$ & $46(40.4)$ & $114(70.8)$ & $0.000 *$ \\
\hline Present & & $13(27.7)$ & $34(72.3)$ & $47(29.2)$ & \\
\hline Stressor & $1(2) ; 0-4$ & & & & \\
\hline None & & $32(65.3)$ & $17(34.7)$ & $49(30.4)$ & $0.016^{*}$ \\
\hline Present & & $49(43.8)$ & $63(56.3)$ & $112(69.6)$ & \\
\hline Coping abilities & $4(3) ; 0-6$ & & & & \\
\hline Present & & $51(61.4)$ & $32(38.6)$ & $83(51.6)$ & $0.005 *$ \\
\hline Not present & & $30(38.5)$ & $48(61.5)$ & $78(48.4)$ & \\
\hline
\end{tabular}


Based on Table 4, significant relationships are noted between instrumental support (AOR=3.177;95\%CI 1.01-9.91), appraisal support (AOR=7.620; 95\%CI 2.83-20.4) from family members and the quality of life among persons with schizophrenia. Additionally, a number of external variables are also associated with quality of life, such as employment status (AOR=5.286; 95\% CI 1.75-15.9), marital status $(\mathrm{AOR}=4.128 ; 95 \% \mathrm{CI} 1.54-11.0)$ and relapse episodes $(\mathrm{OAR}=3.522 ; 95 \% \mathrm{CI} 1.18-10.4)$.

Table 4. AOR of emotional, instrumental, informational, appraisal supports, sociodemographic factors, adherence, relapse, stressor, and coping with high quality of life of persons with schizophrenia

\begin{tabular}{|c|c|c|c|c|}
\hline \multirow{2}{*}{ Variable } & \multirow{2}{*}{ AOR } & \multicolumn{2}{|c|}{$95 \% \mathrm{CI}$} & \multirow{2}{*}{$\mathrm{p}$} \\
\hline & & Lower limit & Upper limit & \\
\hline High emotional support & 1.345 & 0.46 & 3.88 & 0.583 \\
\hline High instrumental support & 3.177 & 1.01 & 9.91 & 0.047 \\
\hline High informational support & 2.515 & 0.85 & 7.42 & 0.095 \\
\hline High appraisal support & 7.620 & 2.83 & 20.4 & 0.000 \\
\hline Employed & 5.286 & 1.75 & 15.9 & 0.003 \\
\hline Married & 4.128 & 1.54 & 11.0 & 0.005 \\
\hline High school equivalent/higher level & 0.978 & 0.39 & 2.44 & 0.961 \\
\hline Adhere to medication & 1.278 & 0.49 & 3.31 & 0.614 \\
\hline Having no stressor & 1.749 & 0.58 & 5.27 & 0.321 \\
\hline Able to coping & 0.615 & 0.21 & 1.76 & 0.365 \\
\hline No relapse episodes & 3.522 & 1.18 & 10.4 & 0.023 \\
\hline
\end{tabular}

\section{DISCUSSION}

Our study reveals that only half of the patients with schizophrenia has high quality of life and receive high family support half of the time. Instrumental and appraisal supports by family members are significantly associated with quality of life, whereas emotional and informational support are not significantly associated with quality of life. Moreover, employment status, marital status and history of relapse episodes are also associated with the quality of life of persons with schizophrenia.

The proportion of persons with schizophrenia reporting high quality of life in our study is $50.3 \%$, lower than the $82.1 \%$ reported in a similar study by Sanchaya [18]. The study by Sanchaya [18] was performed in Denpasar City East Denpasar 2nd Community Health Center (Puskesmas II Denpasar Timur Kota Denpasar), an area with an ongoing Community Mental Health Nursing (CMHN) program. The CHMN program is a mental healthcare service at the community level involving families in the patient's recovery and prevention of relapses. The formation of mental health prepared village (Desa Siaga Jiwa) is one of the CMHN programs oriented toward providing education for mental health patients and their family, activitybased therapy and rehabilitation to promote independence among patients [22]. The formation of mental health awareness program in each village is expected to produce community health workers who care about mental health and support families in providing care independently at home, such that patients with mental illness in the community who are previously neglected can receive optimal mental health care [22]. The development for CMHN strategy has been initiated in Badung Regency, however, it is currently at the stage of information dissemination at the district level. In light of this, our study results may be useful for providing preliminary data prior to implementing the CMHN program in Badung Regency. It is our hope that after implementing CMHN for some time in Badung Regency, there will be increasing number of persons with schizophrenia with high quality of life.

Our study shows that only $51.1 \%$ of families provide high levels of support in overall kinds of supports (including emotional, instrumental, informational, and appraisal), for patients with schizophrenia, with the majority of patients receiving high levels of support reporting high quality of life (73.5\%). This finding is consisted with reviews provided by Calafell's [10], indicating the patients with high levels of family support also report high social functioning and better quality of life. This suggests that family support through stigma reduction in the community may increase quality of life for patients with schizophrenia in the community [23]. The reduction of internalized stigma among patients is closely associated with the social support received, the family's and community's acceptance which increases the ability to work, perform daily activities and adapt to surroundings, whereby the support of family and social environment play important roles in increasing the social function of patients with schizophrenia [24]. High levels of instrumental support from family affects the quality of life of persons with schizophrenia. Instrumental support is strongly associated with financial concerns as most persons with schizophrenia are unemployed and require their family to cover living expenses. The financial dependence among persons with schizophrenia is reported to be associated with relapse episodes, as it increases the person's vulnerability to mental disturbance and frustration which in turn increases the chances of relapsing [25]. In our study, few 
relapses were reported. This is due to the instrumental support by family through finances, facilities and the time provided by family to assist and monitor patients under treatment. This is likely to be perceived by patients as practical and tangible support that resolves the patient's financial concerns [26].

Our study also reveals that appraisal support has the most likely to improve quality of life. Appraisal support form family in the form of giving attention, kind treatment, monitoring, trusting and not restricting activities post discharge or during recovery, provided that others are not bothered, can support the patient's remission [27]. Similarly, outpatients in Purworejo Regency, Central Java, also report that being treated poorly, restricted from leaving, and not trusted to interact socially in the community can increase the occurrence of relapse. Recurring symptoms can worsen the patient's health, making it difficult to attain good quality of life [25].

Out study results indicate that patients with schizophrenia who are employed, are married have never relapsed, have a higher quality of life compared patients who are unemployed, unmarried and experience frequent relapse. Our study further examines the relationship between employment status and quality of life. Literature shows that persons with schizophrenia who work will pay more attention to the quality of their health, able to interact in social situations and receive social support from the community, family, and friends, compared to patients who are unemployed, such that they adhere better to medication regimens [28]. The study by Pinho [14] and Karow [29] reveals that patients with schizophrenia who are employed report much higher scores on all domains of quality of life compared to patients who are unemployed. Our study results also reveal that patients who work are less likely to experience relapse episodes and more likely to have increased quality of life compared to patients who experience relapse. Relapse episodes can progressively decrease the patient's ability to function, worsening patient response to medication and clinical prognosis. The occurrence of relapse is reported to be dependent on the family [12], [25], aside from medication adherence and presence of stressors. Our study shows that most patients with schizophrenia who are employed receive high appraisal support from their family as they are trusted to participate in activities outside the home, albeit still under supervision and guidance from the family. Other benefits reported by patients who are employed include the higher likelihood or being able to get married, whereby marriage fulfills the basic human need for sex and build families [30]. However, another study shows that marriage can either protect or harm the recovery journey for patients with schizophrenia [31]. The impact of marital and employment status on quality of life are still inconclusive, as marital status is found to increase quality of life in one study [15], [32], [33] but found to be unassociated with quality of life in another study [32]-[35].

The limitations of study occurs where characteristics of samples being substituted are not known, potentially affecting study results. Theoretical factors that contribute to low family support such as the knowledge and socioeconomic status of the family, are not examined. Although the researchers and team have been trained to obtain answers from the respondents, it is still possible that the family's presence during interview may affect the answers given.

\section{CONCLUSION}

Elements of family support with significant roles are instrumental and appraisal support, whereas emotional and informational supports are not as significant. In addition, employment, marital status, and occurrence of relapse are associated with the quality of life of persons with schizophrenia. These results can be used to inform decision makers to enhance the family's role in treatment of mental health patients at the family and community level. In planning for mental health programs, further considerations are needed in raising awareness and empowering communities in managing persons with schizophrenia through mental health integrated service clinics (posyandu) at the village level integrated with the health, built into the village or subdistrict structure as Mental Health Awareness Village or Desa Siaga Kesehatan Jiwa.

\section{ACKNOWLEDGEMENTS}

We would like to thank all respondents including all people with schizophrenia and their family who provided valuable time and information for this study. We also appreciate all interviewers who assisted in the data collection. Lastly, thanks to the Head of Badung District Health Office and staff, and the Head of Community Health Centers for allowing the study in their territory.

\section{REFERENCES}

[1] WHO, "Schizophrenia," Switzerland, 2019. [Online]. Available: https://www.who.int/en/news-room/factsheets/detail/schizophrenia.

[2] Global Health Metrics, "Global Regional, and National Disability-adjusted Life-Years (DALY) for 359 Diseases 
and Injuries and Healthy Life Expectancy (HALE) for 195 Countries and Territories, 1990-2017: a Systematic Analysis for the Global Burden of Disease Study 2017," 2019.

[3] Ministry of Health Republic Indonesia, "Main Findings of Basic Health Survei 2018 (In Indonesia: Hasil Utama Riskesdas 2018)," Jakarta, Indonesia, 2018. [Online]. Available: http://www.depkes.go.id/resources/download/infoterkini/materi_rakorpop_2018/Hasil Riskesdas 2018.pdf.

[4] Mental Health Hospital of Bali Province, "Annual Report of Bali Province Mental Health Hospital Year 2018 (Laporan Tahunan Rumah Sakit Jiwa Provinsi Bali Tahun 2018),” Bangli, 2019.

[5] Badung District Health Office, "Annual Report of Division of Prevention and Control of Non Communicable Diseases and Mental Health Year 2018 (In Indonesia: Laporan Tahunan Seksi Pencegahan dan Penanggulangan Penyakit Tidak Menular dan Kesehatan Jiwa Tahun 2018)," Badung, 2019.

[6] Ministry of Health Republic Indonesia, Ministry of Health Regulation Number 4 Year 2019 of Technical Standard of Fulfilling Quality of Basic Services to Minimal Services in Health Area (Peraturan Menteri Kesehatan Republik Indonesia Nomor 4 Tahun 2019 tentang Standar Teknis Pemenuhan Mutu Pela. Indonesia, 2019, pp. 1-139.

[7] S. K. Chaturvedi and K. P. Muliyala, "The Meaning in Quality of Life," J. Psychosoc. Rehabil. Ment. Heal., vol. 3, no. 2, pp. 47-49, Dec. 2016, doi: 10.1007/s40737-016-0069-2.

[8] Z. Cernovsky, "Quality of life in persons with schizophrenia," Ment. Illn., vol. 9, no. 1, pp. 1-2, 2017, doi: 10.4081/mi.2017.7052.

[9] S. Durgoji, K. P. Muliyala, D. Jayarajan, and S. K. Chaturvedi, "Quality of Life in Schizophrenia: What is Important for Persons with Schizophrenia in India?," Indian J. Psychol. Med., vol. 41, no. 5, pp. 420-427, 2019, doi: 10.4103/IJPSM.IJPSYM_71_19.

[10] M. Rus-Calafell, A. Caqueo-Urízar, A. Urzúa, J. Escudero, and J. Gutiérrez-Maldonado, "The Role of Family Therapy in the Management of Patients with Schizophrenia: Challenges and Solutions," Neuropsychiatr. Dis. Treat., p. 145, Jan. 2015, doi: 10.2147/NDT.S51331.

[11] H. Sari and F. Fina, "Family Support to Prevent Relapse of Schizophrenia Patients at Aceh Policlinic of Mental Health Hospital (In Indonesia: Dukungan Keluarga dalam Mencegah Kekambuhan Pasien Skizofrenia di Poliklinik Rawat Jalan RSJ Aceh)," Nurs. J. (Manila)., vol. II, no. 3, pp. 176-186, 2011, [Online]. Available: http://www.jurnal.unsyiah.ac.id/INJ/article/view/6380/5241.

[12] R. H. Simanullang, "The Correlation Between Family Support and Relapse in Schizophrenia at the Psychiatric Hospital,” Belitung Nurs. J., vol. 4, no. 6, pp. 566-571, Nov. 2018, doi: 10.33546/bnj.389.

[13] K. Karmila, D. R. Lestari, and H. Herawati, "Family Support with Adherence of Drug Consumption in Community Health Center of Banjarbaru (In Indonesia: Dukungan Keluarga dengan Kepatuhan Minum Obat pada Pasien Gangguan Jiwa di Wilayah Kerja Puskesmas Banjarbaru)," Dunia Keperawatan, vol. 4, no. 2, p. 88, Jan. 2017, doi: $10.20527 / \mathrm{dk} . v 4 \mathrm{i} 2.2558$.

[14] L. M. Guedes de Pinho, A. M. de S. Pereira, and C. M. C. B. Chaves, "Quality of Life in Schizophrenic Patients: the Influence of Sociodemographic and Clinical Characteristics and Satisfaction with Social Support," Trends Psychiatry Psychother., vol. 40, no. 3, pp. 202-209, Mar. 2018, doi: 10.1590/2237-6089-2017-0002.

[15] D. R. B. Prasetyo, W. A. Puspitosari, and I. Rochmawati, "Association of Demographic Factors with Quality of Life of Schizophrenia Patients (In Indonesia: Hubungan Faktor Demografi dengan Kualitas Hidup Pasien Skizofrenia)," Skripsi, Universitas Muhamadyah Yogyakarta, 2016.

[16] D. Desalegn, S. Girma, and T. Abdeta, "Quality of Life and Its Association with Psychiatric Symptoms and Sociodemographic Characteristics among People with Schizophrenia: A Hospital-based Cross-sectional Study," PLoS One, vol. 15, no. 2, Feb. 2020, doi: 10.1371/journal.pone.0229514.

[17] M. W. Z. Lim and J. Lee, "Determinants of Health-Related Quality of Life in Schizophrenia: Beyond the Medical Model," Front. Psychiatry, vol. 9, no. December, pp. 1-9, 2018, doi: 10.3389/fpsyt.2018.00712.

[18] K. Sanchaya, M. N. Sulistiowati, and P. N. Darma, "Association of Family Support with Quality of Life of People with Mental Disorder (In Indonesia: Hubungan Dukungan Keluarga Dengan Kualitas Hidup Orang Dengan Gangguan Jiwa)," J. Ilmu Keperawatan Pus. Pengemb. Keperawatan Jawa Teng., vol. 1, no. 2, pp. 87-92, 2018.

[19] WHO, "The World Health Organization Quality of Life (WHOQOL)-BREF Version Indonesia," Geneva Switzerland, 2004.

[20] M. M. Friedman, V. R. Bowden, and E. G. Jones, Family Nursing: Research, Theory and Practice (In Indonesia: Buku Ajar Keperawatan Keluarga: Riset, Teori dan Praktek), 5th ed. Jakarta, Indonesia: EGC Jakarta, 2010.

[21] M. Krousel-Wood, T. Islam, L. S. Webber, R. N. Re, D. E. Morisky, and P. Muntner, "New Medication Adherence Scale Versus Pharmacy Fill Rates in Seniors with Hypertension,” Am. J. Manag. Care, vol. 15, no. 1, pp. 59-66, Jan. 2009.

[22] A. S. Putri et al., "The New Era of Mental Health in Indonesia: A Story from Mental Health Awareness Village (In Indonesia: Era Baru Kesehatan Mental Indonesia: sebuah Kisah dari Desa Siaga Sehat Jiwa (DSSJ))," J. Psikol. $U G M$, vol. 40, no. 2, pp. 169-180, 2014, doi: 10.22146/jpsi.6975.

[23] E. E. Erawati and B. K. B. A. Keliat, "The Family Support for Schizophrenia Patients On Community a Case Study," Eur. Psychiatry, vol. 30, p. 917, Mar. 2015, doi: 10.1016/S0924-9338(15)30716-1.

[24] M. Mashiach-Eizenberg, I. Hasson-Ohayon, P. T. Yanos, P. H. Lysaker, and D. Roe, "Internalized Stigma and Quality of Life among Persons with Severe Mental Illness: The Mediating Roles of Self-esteem and Hope," Psychiatry Res., vol. 208, no. 1, pp. 15-20, Jun. 2013, doi: 10.1016/j.psychres.2013.03.013.

[25] E. Setiati, D. Sumarni, and S. Suryawati, "Social Support and Medication Obedience with Recurrence of Schizophrenia Patients in Purworejo (In Indonesia: Dukungan Sosial dan Ketaatan Pengobatan dengan Kekambuhan Pasien Skizofrenia di Purworejo)," Ber. Kedokt. Masy., vol. 33, no. 6, 2017. 
[26] A. S. Ningrum and A. Sumarno, "Association Between Family Support with Relapse among Schizophrenia Patients at Mental Health Policlinic Duren Sawit Hospital, East Jakarta (In Indonesia: Hubungan Dukungan Keluarga dengan Kekambuhan Klien Skizofrenia di Poliklinik Psikiatri Rumah Sakit Duren Sawit Jak)," J. AFIAT Kesehat. dan Anak, vol. 4, no. 2, 2018.

[27] A. Yusuf, R. P. Fitryasari, H. E. Nihayati, and D. R. Tristiana, Mental Health: Holistic Approach in Nursing care (In Indonesia: Kesehatan Jiwa: Pendekatan Holistik dalam Asuhan Keperawatan), 1st ed. Jakarta, Indonesia: Mitra Wacana Media Jakarta, 2019.

[28] I. Wardani and F. Dewi, "Quality of Life of Schizophrenia Patients being Perceived as Self-stigma (In Indonesia: Kualitas Hidup Pasien Skizofrenia Dipersepsikan Melalui Stigma Diri).," J. Keperawatan Indones., vol. 21, no. 1, pp. 17-26, 2018.

[29] Anne Karow, L. Wittmann, D. Schöttle, I. Schäfer, and M. Lambert, "The assessment of quality of life in clinical practice in patients with schizophrenia," AICH-Servier Research Group, 2014. [Online]. Available: www.dialogues-cns.org

[30] A. Srivastava, "Marriage as a Perceived Panacea to Mental Illness in India: Reality Check," Indian J. Psychiatry, vol. 55, no. 6, 2013, doi: 10.4103/0019-5545.105542.

[31] V. Deshmukh, A. Bhagat, N. Shah, S. Sonavane, and A. Desousa, "Factors Affecting Marriage in Schizophrenia: A Cross-sectional Study," J. Ment. Heal. Hum. Behav., vol. 21, no. 2, 2016, doi: 10.4103/0971-8990.193432.

[32] Y. Huang, C. Wang, and D. Ph, "The Relationship between Quality of Life and Marital Status in Patients with Schizophrenia," vol. 27, no. 2, pp. 121-130, 2013.

[33] X. J. Li et al., "The influence of marital status on the social dysfunction of schizophrenia patients in community," Int. J. Nurs. Sci., vol. 2, no. 2, pp. 149-152, 2015, doi: 10.1016/j.ijnss.2015.04.015.

[34] C. Bouwmans, C. De Sonneville, C. L. Mulder, and L. Hakkaart-van Roijen, "Employment and the associated impact on quality of life in people diagnosed with schizophrenia," Neuropsychiatr. Dis. Treat., vol. 11, pp. 21252142, 2015, doi: 10.2147/NDT.S83546.

[35] V. R. Carmona, J. Gómez-Benito, T. B. Huedo-Medina, and J. E. Rojo, "Employment outcomes for people with schizophrenia spectrum disorder: A meta-analysis of randomized controlled trials," Int. J. Occup. Med. Environ. Health, vol. 30, no. 3, pp. 345-366, 2017, doi: 10.13075/ijomeh.1896.01074. 